\title{
ACUTE CONTACT TOXICITY TEST OF OXALIC ACID ON HONEYBEES IN THE SOUTHWESTERN ZONE OF URUGUAY
}

\author{
Leonidas Carrasco-Letelier ${ }^{1 *}$, Yamandú Mendoza ${ }^{1}$, and Gustavo Ramallo ${ }^{1}$
}

This work studies the acute contact toxicity of oxalic acid (OA) on a honeybee polyhybrid subspecies (Apis mellifera), which is the dominant biotype in southwestern zone of Uruguay (SWZU) and the country's most important honey-producing region. We determined the mean lethal dose $\left(\mathrm{LD}_{50}\right)$, as well as the no observed effect level (NOEL) and the lowest observed effect level (LOEL) values. We also estimated the total number of honeybees per hive in the test area. The aim was to assess the relationship between the maximum OA dose used in Uruguay (3.1 g OA per hive) and the toxicological parameters of honeybees from SWZU. The current dose of $3.1 \mathrm{~g} \mathrm{OA}$ per hive corresponds to $132.8 \mu \mathrm{g}$ OA per honeybee since determined NOEL is $400 \mu \mathrm{g}$ OA per honeybee; our results indicate that the current dose could be increased to $9.3 \mathrm{~g}$ OA per hive. The results also highlight some differences between the $\mathrm{LD}_{50}$ value in SWZU honeybees $(548.95 \mu \mathrm{g}$ OA per honeybee) and some published $\mathrm{LD}_{50}$ values for other honeybee subspecies.

Key words: $\mathrm{LD}_{50}$, Varroa destructor, Uruguay.

$\mathrm{B}$ eekeeping is an economically important agricultural activity in Uruguay with annual exports of honey contributing more than $0.5 \%$ of gross domestic product (approximately US\$28 million) according to DIEA (2009) statistics. This percentage could be increased if the various problems that adversely affect honey production in Uruguay were addressed (Mendoza et al., 2008). Currently, the main biological factor harming honey production in Uruguay is the prevalence of varroosis (the infection of hives caused by the mite Varroa destructor) (Mendoza et al., 2008). However, efforts to control mites with synthetic miticides (normally with xenobiotic characteristics) have led to two additional problems, that is, an increase in the risk of selecting resistant $V$. destructor strains (Lodesani et al., 1995; Elzen et al., 2000; Thompson et al., 2002; Pettis, 2004) and an increase in the risk of hive products by miticides (e.g., coumaphos) (Wallner, 1999; Tremolada et al., 2004). More specifically, the first problem has led to a progressive decrease in the efficacy of synthetic acaricides to control resistant $V$. destructor strains.

For these reasons, the study of chemical compounds with miticidal characteristics has become relevant, particularly those chemical compounds normally found in hives or essential oils, such as oxalic acid (OA) (Prandin et al., 2001; Gregorc and Planinc, 2001; 2002; Marcangeli et al., 2003, Nanetti et al., 2003; Marinelli et al., 2006;

${ }^{1}$ Instituto Nacional de Investigación Agropecuaria (INIA), Estación Experimental Alberto Boerger INIA La Estanzuela, Ruta 50, km 11, Colonia, Uruguay. "Corresponding author (lcarrasco@inia.org.uy). Received: 6 July 2011.

Accepted: 17 May 2012.
Rademacher and Harz, 2006; Bacandritsos et al., 2007), formic acid (Calderone, 2000; Bogdanov et al., 2002; Eguaras et al., 2003), and thymol (Imdorf et al., 1995). This type of compounds do not pollute a hive's products (Bogdanov et al., 2002) or produce resistant V. destructor strains. As a result, OA is one of the chemicals most often used as a complementary miticide (Prandin et al., 2001; Gregorc and Planinc, 2001; 2002; Nanetti et al., 2003; Marcangeli et al., 2003, Marcangeli and García, 2004; Marinelli et al., 2006; Rademacher and Harz, 2006; Bacandritsos et al., 2007). Nevertheless, although some studies have reported the toxic activity of OA against $V$. destructor, few have examined its toxic effect on honeybees (Gregorc and Planinc, 2002) because it is normally assumed that the doses used are of low toxicity (Marcangeli et al., 2003; Marcangeli and García, 2004). Furthermore, scientific advice about using OA is based on studies of Apis mellifera mellifera rather than on the honeybee polyhybrid subspecies (Diniz et al., 2003) found in southwestern zone of Uruguay (SWZU) (Figure 1). It is necessary to determine the acceptable dose of OA for the dominant SWZU polyhybrid subspecies because the acute toxicological response can differ between species (Suchail et al., 2000). The suggested OA dose is estimated per hive and based on a certain number of honeybees; however, these factors may be different in SWZU because of the local environmental conditions and the genetic mixture of Apis mellifera scutellata (Fewell and Bertram, 2002; Diniz et al., 2003; Carrasco-Letelier et al., 2012). There is also a lack of agreement between OA doses used and suggested in Uruguay (Campá et al., 2007; Ramallo et al., 2008) and the doses recommended 


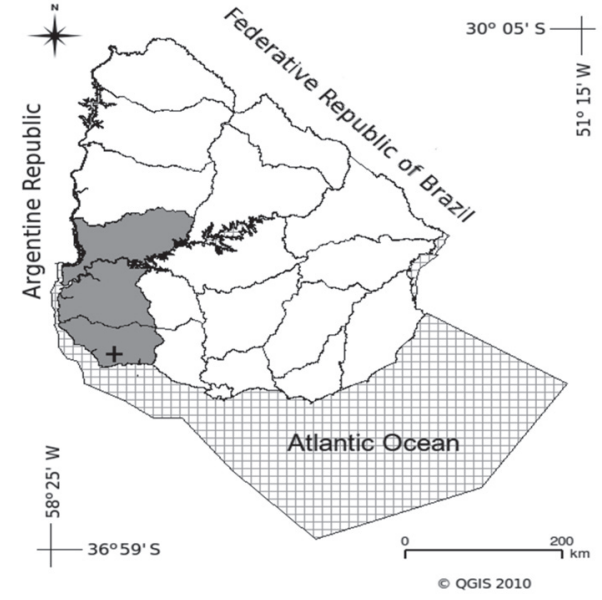

Figure 1. Geographic position of southwestern Uruguay (dark gray) and the Experimental Station, INIA-La Estanzuela (black cross) on a political map of the Oriental Republic of Uruguay.

in other studies, such as those by Aliano et al. (2006) and Martín-Hernández et al. (2007). In Uruguay, the OA dose is normally applied by trickling $5 \mathrm{~mL}$ per bee space (30-50 mL per hive) in a sucrose solution 1:1; a dose of $62.6 \mathrm{~g} \mathrm{~L}^{-1}$ (Campá et al., 2007) is administered in summer with brood as a strategy to reduce the varroa population, avoid the use of synthetic miticides, and allow a better performance of synthetic miticides in autumn. This is similar to the practice in Argentina, country from which the OA formulation Oxavar® (Apilab, Buenos Aires, Argentina) is imported (Campá et al., 2007).

Our aim in this study was to determine the upper limit of the OA dose that could be used on the dominant polyhybrid subspecies in SWZU without generating toxic problems for this type of honeybee. We determined a lethal dose $\left(\mathrm{LD}_{50}\right)$ value for $\mathrm{OA}$ with a 48 -h bioassay with newborn bees of the SWZU biotype; we also determined the no observed effect level (NOEL), the lowest observed effect level (LOEL), number of bees per hive, and the data required to define an adequate dose per hive.

\section{MATERIALS AND METHODS}

The honeybee we used in this study belongs to the polyhybrid subspecies of A. mellifera from SWZU. Bees were obtained from experimental apiaries kept by the Beekeeping Unit of the Experimental Station Alberto Boerger, INIA La Estanzuela, Colonia, Uruguay $\left(34^{\circ} 20^{\prime} 22.20^{\prime} \mathrm{S}, 57^{\circ} 41^{\prime} 14.93^{\prime} \mathrm{W}\right)$. The honeybees in the bioassays were newborn bees (aged 1-7 d) from hive frames isolated with plastic mesh bags (square cells, $1 \times 1$ $\mathrm{mm}$ ) in the hives with no treatment against varroosis. The honeybees were closely monitored after treatment and then observed for mortality and signs of intoxication after $48 \mathrm{~h}$.

The bioassay of acute toxicity was developed in accordance with criteria from the United States Environmental Protection Agency (US EPA, 1996): 48 h in the dark, $60 \%$ humidity, and temperature-controlled ( 25 $\left.{ }^{\circ} \mathrm{C}\right)$ conditions. Five doses of OA $(200,400,600,800$, and $1000 \mu \mathrm{g}$ OA per bee, all with a diluent of sucrose solution $1: 1 \mathrm{v} / \mathrm{v}$ ) were tested in the bioassay with five replicates for each one. Each replicate consisted of 10 honeybees. Each dose of OA $\left(\mathrm{C}_{2} \mathrm{H}_{2} \mathrm{O}_{4} 2 \mathrm{H}_{2} \mathrm{O}\right.$, Biopack, Buenos Aires, Argentina) was applied on the honeybee's thorax with a micropipette. Five hives were randomly selected from an apiary of 50 hives; two honeybees were taken from each selected hive to make up the group of 10 for each replicate. The formation of each group and the thoracic dose were carried out by anesthetizing the honeybees with $\mathrm{CO}_{2}$ (g) (US EPA, 1996). Each group of 10 honeybees was kept in a glass Petri dish (I.D. $10 \mathrm{~cm}$ ) lined with clean filter paper and containing a feeder with $1 \mathrm{~mL}$ sucrose $50 \% \mathrm{w} / \mathrm{v}$ for ad libitum consumption. A procedure similar to the one described above was carried out for the control treatment with five replicates, but the thoracic dose of OA was replaced with acetone.

We selected five other hives from the same apiary to estimate the number of honeybees per hive. Hives were closed at night and the bees killed by saturating the hive with diesel vapors. The next morning, all the bees in each hive were collected and weighed; two subsamples were also weighed and manually counted to estimate the number of honeybees in each hive. All the experiments were carried out in the summer of 2009 (January and February). The colonies were not infested by varroa at a level higher than $1 \%$ or by Nosema.

The $\mathrm{LD}_{50}$ was determined by the nonparametric trimmed Spearman-Karber test (Hamilton et al., 1977; Hamilton, 1979). This test was run with the TSK version 1.5 software from the US EPA (2006) in DOS emulation with DOSEMU 1.4.0 (DOSEMU.org, 2010) on a GNU/ Linux operating system (Canonical, 2010). NOEL and LOEL were determined by one-way ANOVA after assessing the normal distribution and homogeneity of variance by the Shapiro-Wilk and Levene tests, respectively. The determined mean $\mathrm{LD}_{50}$ value was compared with those reported by Aliano et al. (2006) (372.01 $\mu \mathrm{g}$ OA per honeybee) and Martín-Hernández et al. (2007) (530 $\mu \mathrm{g}$ OA per honeybee). This was compared by Student's $t$ test for a single sample after assessing the normal distribution and homogeneity of variance by the Shapiro-Wilk and Levene tests, respectively.

All the statistical tests were run with the statistical package $\mathrm{R}$ version 2.12.0 (R Development Core Team, 2010) for the platform i486-pc-Linux-gnu (32-bit) with R Commander 1.5-4 (Fox, 2005; R Development Core Team, 2010) on a GNU/Linux operating system (Canonical, 2010).

\section{RESULTS}

The results of the bioassay agreed with the criteria of the US EPA for a mortality rate in the control treatment (US 
EPA, 1996). Moreover, the characteristics of the results satisfied the requirements of the trimmed SpearmanKarber test (Table 1). The determined $\mathrm{LD}_{50}$ was in the range of 446.42-736.87 $\mu \mathrm{g}$ OA per honeybee with a mean value of $548.95 \mu \mathrm{g}$ OA per honeybee, a standard deviation of $114.55 \mu \mathrm{g}$ OA per honeybee, and a $95 \%$ confidence interval of 406.72-691.19 $\mu \mathrm{g}$ OA per honeybee (Table 1).

Analysis of the mortality rates showed homogeneity of variance $(\mathrm{p}=0.3411)$, but not a normal distribution $(\mathrm{p}=$ 0.0004). Therefore, we performed a Kruskal-Wallis rank sum test which revealed significant statistical differences $\left(\chi^{2}=23.0747\right.$, df $\left.=5, p=0.0003\right)$. For this result, the mortality rate of the control treatment was compared with values obtained using different doses of OA and the Wilcoxon signed-rank test. This allowed us to determine NOEL and LOEL as $400 \mu \mathrm{g}$ OA per honeybee $(\mathrm{p}=0.1797)$ and $600 \mu \mathrm{g}$ OA per honeybee $(\mathrm{p}=0.0431)$, respectively.

Biomass assessment in SWZU hives revealed a range of 1384.8-2780.7 $\mathrm{g}$ of honeybees per hive $\left(\mathrm{ghb} \mathrm{h}^{-1}\right)$, a mean value of $2382.1 \mathrm{ghb} \mathrm{h}^{-1}$, and a standard deviation of $564.8 \mathrm{ghb} \mathrm{h}^{-1}$. When this assessment was performed for the population in SWZU hives, the results showed a range of 15 508.6-27 618.9 honeybees per hive $\left(\mathrm{hb} \mathrm{h}^{-1}\right)$, a mean value of $23350 \mathrm{hb} \mathrm{h}^{-1}$, and a standard deviation of 4640.1 $\mathrm{hb} \mathrm{h}^{-1}$ (Table 2). The measurements had a $95 \%$ confidence interval of $1680.8-3083.5 \mathrm{ghb} \mathrm{h}^{-1}$ for the biomass mean value and $17588.1-29111.0 \mathrm{hb} \mathrm{h}^{-1}$ for the population mean value.

\section{DISCUSSION}

The $\mathrm{LD}_{50}$ mean value determined in our study is not statistically different from zero when compared with the value reported in Martín-Hernández et al. (2007). However, it is statistically different $(\mathrm{P}=0.0260)$ when compared with the value in Aliano et al. (2006). These statistical comparisons suggest that honeybees in SWU have a similar toxicological response to Apis mellifera iberiensis used by Martín-Hernández et al. (2007), but not to A. mellifera L. used by Aliano et al. (2006) and in other studies (Gregorc and Planinc, 2001; Aliano and Ellis, 2009). Therefore, we suggest that research using OA in varroosis control associated with A. mellifera iberiensis
Table 2. Number and biomass of honeybees per hive in a representative apiary in southwestern Uruguay.

\begin{tabular}{|c|c|c|c|c|}
\hline Hive $\mathrm{N}^{\mathrm{o}}$ & Biomass & $\begin{array}{c}\text { Subsample } \\
\text { weight }\end{array}$ & $\begin{array}{l}\text { Honeybees } \\
\text { per sample }\end{array}$ & $\begin{array}{c}\text { Honeybees } \\
\text { per hive }\end{array}$ \\
\hline \multirow[t]{3}{*}{13} & 2624.3 & 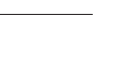 & & 25561.6 \\
\hline & & 383.73 & 3712 & \\
\hline & & 272.35 & 2671 & \\
\hline \multirow[t]{3}{*}{31} & 1384.8 & & & 15508.6 \\
\hline & & 205.88 & 2308 & \\
\hline & & 140.33 & 1570 & \\
\hline \multirow[t]{3}{*}{47} & 2574.8 & & & 23482.5 \\
\hline & & 313.98 & 2878 & \\
\hline & & 329.73 & 2992 & \\
\hline \multirow[t]{3}{*}{57} & 2780.7 & & & 27618.9 \\
\hline & & 296.75 & 3011 & \\
\hline & & 398.43 & 3872 & \\
\hline \multirow[t]{3}{*}{129} & 2546.1 & & & 24575.9 \\
\hline & & 258.95 & 2469 & \\
\hline & & 377.58 & 3689 & \\
\hline Mean & 2382.1 & & & 23349.5 \\
\hline SD & 564.84 & & & 4640.11 \\
\hline
\end{tabular}

should be considered as a guide to manage the SWU honeybee polyhybrid subspecies.

We can extrapolate these results to the trickling method that is commonly used in Uruguay by considering the product of NOEL (400 $\mu \mathrm{g}$ OA per honeybee) and the mean number of bees per hive $\left(23350 \mathrm{hb} \mathrm{h}^{-1}\right)$ to suggest that the maximum dose of OA should be $9.3 \mathrm{~g}$ per SWZU hive (i.e., without expecting a significant loss of honeybees). Based on the range of the number of bees per hive, the maximum dose of OA could vary from 7.0 to $11.6 \mathrm{~g}$ per hive. The suggested $3.1 \mathrm{~g}$ per hive dose in Ramallo et al. (2008) is therefore $6.2 \mathrm{~g}$ lower than the maximum OA dose calculated in this study based on the NOEL value. These results imply that there could be further opportunities to control $V$. destructor in SWZU hives with OA and suggest that higher doses of OA might be used along with concomitant reductions in the dose and frequency of synthetic miticide applications (fluvalinate, amitraz, coumaphos, and flumethrin). Making such changes could lead to improved management and risk reduction associated with resistant $V$. destructor strains and pollution by synthetic miticides (Tremolada et al., 2004). Furthermore, changes in practices based on these results could facilitate Uruguayan honey exports to Europe where the use of $\mathrm{OA}$ is permitted and there are no

Table 1. Mortality rate, mean lethal dose $\left(\mathrm{LD}_{50}\right)$, and $95 \%$ confidence intervals of acute toxicological bioassay with newborn honeybees from southwestern Uruguay.

\begin{tabular}{|c|c|c|c|c|c|c|c|}
\hline \multirow{2}{*}{$\begin{array}{l}\text { Dose } \\
\text { (g oxalic acid per bee) }\end{array}$} & \multicolumn{5}{|c|}{ Bioassay result } & \multirow[b]{2}{*}{ Mean } & \multirow[b]{2}{*}{$\mathrm{SD}$} \\
\hline & 1 & 2 & 3 & 4 & 5 & & \\
\hline 200 & 0.2 & 0.0 & 0.0 & 0.1 & 0.1 & & \\
\hline 400 & 0.1 & 0.1 & 0.4 & 0.2 & 0.0 & & \\
\hline 600 & 0.9 & 1.0 & 0.7 & 0.3 & 0.6 & & \\
\hline 800 & 1.0 & 1.0 & 1.0 & 0.8 & 1.0 & & \\
\hline 1000 & 0.7 & 0.9 & 1.0 & 0.5 & 0.9 & & \\
\hline $\mathrm{LD}_{50}$ calculated by TSK & 501.58 & 486.96 & 446.42 & 736.87 & 572.94 & 548.95 & 114.55 \\
\hline Upper limit $95 \%$ CI & 538.86 & 534.48 & 543.15 & 875.29 & 648.74 & & \\
\hline Lower limit $95 \%$ CI & 466.00 & 436.33 & 366.92 & 620.35 & 506.00 & & \\
\hline SK-Trim $(\%)$ & 14.81 & 3.51 & 0 & 38.89 & 5.36 & & \\
\hline
\end{tabular}

TSK: Trimmed Spearman-Karber test; SK-Trim: Spearman-Karber trim; CI: confidence interval; SD: standard deviation. 
maximum OA residue levels (Bogdanov, 2006). However, it must be noted that this study was conducted under acute toxicity conditions, and the results cannot be used to determine the response of hives under chronic exposure, such as those studied by Higes et al. (1999).

\section{CONCLUSIONS}

Based on the results of this study, we conclude that the maximum dose for OA with no effect (NOEL) is $9.2 \mathrm{~g}$ per SWZU hive in acute toxicity conditions, which indicates the maximum range that should be used in future chronic field trials. Moreover, $\mathrm{LD}_{50}$ for $\mathrm{OA}$ in the dominant honeybee polyhybrid subspecies in SWZU is $548.95 \mu \mathrm{g}$ OA per honeybee.

\section{ACKNOWLEDGEMENTS}

This work was financed by the INIA-Sa07 Grant (INIAUruguay). We thank S. Díaz and M. Vera for their laboratory assistance. We also thank the organizations that shared their free software (Ubuntu, GNOME, LibreOffice, R-cran, TSK, DOSEMU, and Quantum QGIS).

Prueba de toxicidad aguda por contacto de ácido oxálico en abejas de la zona sudoeste de Uruguay. Este trabajo estudió la toxicidad aguda por contacto del ácido oxálico (AO) sobre una subespecie poli-híbrida de abejas (Apis mellifera), la cual es el biotipo dominante en la zona sudoeste de Uruguay (SWZU), la región más importante para la producción de miel en este país. Este estudio determinó la dosis letal 50 ( $\mathrm{DL}_{50}$ ), así como el nivel de efecto no observado (NOEL), el nivel de efecto mínimo observado (LOEL), y el número total de individuos por colmena. El propósito fue evaluar la relación entre la dosis máxima de AO usada en Uruguay (3.1 g AO por colmena) y los parámetros toxicológicos de las abejas de la SWZU. Los resultados mostraron que es posible elevar la dosis actual de $\mathrm{AO}$ por colmena a $9.3 \mathrm{~g}$, ya que la dosis actual de $3.1 \mathrm{~g}$ de AO corresponde a $132.8 \mu \mathrm{g}$ AO por abeja, y el NOEL determinado es $400 \mu \mathrm{g}$ AO por abeja. Los resultados también destacaron algunas diferencias entre la $\mathrm{DL}_{50}$ de las abejas del SWZU (548.95 $\mu \mathrm{g}$ AO por abeja) y algunos valores de $\mathrm{DL}_{50}$ publicados para otras subespecies de abejas.

Palabras clave: $\mathrm{DL}_{50}$, Varroa destructor, Uruguay.

\section{LITERATURE CITED}

Aliano, N.P., and M.D. Ellis. 2009. Oxalic acid: A prospective tool for reducing Varroa mite populations in package bees. Experimental and Applied Acarology 48:303-309.

Aliano, N.P., M.D. Ellis, and B.D. Siegfried. 2006. Acute contact toxicity of oxalic acid to Varroa destructor (Acari: Varroidae) and their Apis mellifera (Hymenoptera: Apidae) hosts in laboratory bioassays. Journal of Economic Entomology 99:1579-1582.
Bacandritsos, N., I. Papanastasiou, C. Saitanis, A. Nanetti, and E. Roinioti. 2007. Efficacy of repeated trickle applications of oxalic acid in syrup for varroosis control in Apis mellifera: Influence of meteorological conditions and presence of brood. Veterinary Parasitology 148:174-178.

Bogdanov, S. 2006. Contaminants of bee products. Apidologie 37:118.

Bogdanov, S., J. Charrière, A. Imdorf, V. Kilchenmann, and P. Fluri 2002. Determination of residues in honey after treatments with formic and oxalic acid under field conditions. Apidologie 33:399-409.

Calderone, N.W. 2000. Effective fall treatment of Varroa jacobsoni (Acari: Varroidae) with a new formulation of formic acid in colonies of Apis mellifera (Hymenoptera: Apidae) in the northeastern United States. Journal of Economic Entomology 93:1065-1075.

Campá, J., J. Harriet, and Y. Mendoza. 2007. Cartilla ํ5: Pautas sanitarias para manejar correctamente la varroasis. Otros documentos $\mathrm{N}^{\circ} 21$, INIA La Estanzuela, Colonia, Uruguay. Available at http://lafamiliapicola.blogspot.com/2011/07/pautassanitarias-para-manejar.html (accessed January 2012).

Canonical. 2010. Ubuntu desktop 10.04 LTS. Canonical Group Limited, Millbank Tower, London, UK. Available at <http://www. ubuntu.com/start-download?distro=server\&bits=32\&release $=1$ ts $>$ (accessed April 2010).

Carrasco-Letelier, L., Y. Mendoza, and M.B. Branchiccela. 2012. Acute contact toxicity test of insecticides (Cipermetrina 25 Lorsban 48E, Thionex 35) on honeybees in the southwestern zone of Uruguay. Chemosphere (In press).

DIEA. 2009. Anuario estadístico agropecuario 2009. 223 p. Dirección de Estadísticas Agropecuarias (DIEA), Ministerio de Agricultura, Ganadería y Pesca. Editorial Hemisferio Sur, Montevideo, Uruguay.

Diniz, N.M., A.E.E. Soares, W.S. Sheppard, and M.A. Del Lama. 2003. Genetic structure of honeybee populations from southern Brazil and Uruguay. Genetics and Molecular Biology 26:47-52.

DOSEMU.org. 2010. DOSEMU 1.4.0, GNU general public license. Free software foundation Inc. Available at http://dosemu.org/ stable/ (accessed July 2010).

Eguaras, M., M.A. Palacio, C. Faverin, M. Basualdo, M.L. Del Hoyo, G. Velis, and E. Bedascarrasbure. 2003. Efficacy of formic acid in gel for Varroa control in Apis mellifera L.: Importance of the dispenser position inside the hive. Veterinary Parasitology 111:241-245.

Elzen, P.J., J.R. Baxter, M. Spivak, and W.T. Wilson. 2000. Control of Varroa jacobsoni Oud. resistant to fluvalinate and amitraz using coumaphos. Apidologie 31:437-441.

Fewell, J.H., and S.M. Bertram. 2002. Evidence for genetic variation in worker task performance by African and European honey bees. Behavioral Ecology and Sociobiology 52:318-325.

Fox, J. 2005. The R Commander: A basic-statistics graphical user interface to R. Journal of Statistical Software 14:1-42.

Gregorc, A., and I. Planinc. 2001. Acaricidal effect of oxalic acid in honeybee (Apis mellifera) colonies. Apidologie 32:333-340.

Gregorc, A., and I. Planinc. 2002. The control of Varroa destructor using oxalic acid. The Veterinary Journal 163:306-310.

Hamilton, M.A. 1979. Robust estimates of the ED50. Journal of the American Statistical Association 74:344-354.

Hamilton, M.A., R.C. Russo, and R.V. Thurston. 1977. Trimmed Spearman-Karber method for estimating median lethal concentrations in toxicity bioassays. Environmental Science and Technology 11:714-719.

Higes, M., A. Meana, M. Suárez, and J. Llorente. 1999. Negative long-term effects on bee colonies treated with oxalic acid against Varroa jacobsoni Oud. Apidologie 30:289-292.

Imdorf, A., V. Kilchenmann, S. Bogdanov, B. Bachofen, and C. Beretta. 1995. Toxizität von Thymol, Campher, Menthol und Eucalyptol auf Varroa jacobsoni Oud. und Apis mellifera L. im Labortest. Apidologie 26:27-31.

Lodesani, M., M. Colombo, and M. Spreafico. 1995. Ineffectiveness of Apistan ${ }^{\circledR}$ treatment against the mite Varroa jacobsoni Oud. in several districts of Lombardy (Italy). Apidologie 26:67-72. 
Marcangeli, J.A., and M.C. García. 2004. Effect of Apis mellifera (Apidae) honeybee brood amount on Oxavar ${ }^{\circledR}$ acaricide efficacy against the mite Varroa destructor (Varroidae). Revista de la Sociedad de Entomología Argentina 63:35-38.

Marcangeli, J.A., M.C. García, G. Cano, L. Distefano, M.L. Martín, A. Quiroga, F. Raschia, and C. Vega. 2003. Eficacia del Oxavar® para el control del ácaro Varroa destructor (Varroidae) en colmenas de Apis mellifera (Apidae). Revista de la Sociedad de Entomología Argentina 62:75-79.

Marinelli, E., G. Formato, G. Vari, and F.M. De Pace. 2006. Varroa control using cellulose strips soaked in oxalic acid water solution. Apiacta 41:54-59.

Martín-Hernández, R., M. Higes, J.L. Pérez, M.J. Nozal, L. Gómez, and A. Meana. 2007. Short term negative effect of oxalic acid in Apis mellifera iberiensis. Journal of Agricultural Research 5:474480.

Mendoza, Y., G. Ramallo, S.C. Díaz-Cetti, M.P. Ojeda, and L. Carrasco-Letelier. 2008. Factores predisponentes, pautas sanitarias y medidas de control que se deben integrar para manejar el control de la varroasis. In Jornada de Divulgación: Manejo Sanitario en Apicultura, Colonia. Julio 2008. Serie Actividades de Difusión 539:11-15. INIA La Estanzuela, Colonia, Uruguay.

Nanetti, A., R. Büchler, J.D. Charriere, I. Friesd, S. Helland, A. Imdorf, et al. 2003. Oxalic acid treatments for varroa control (Review). Apiacta 38:81-87.

Pettis, J.S. 2004. A scientific note on Varroa destructor resistance to coumaphos in the United States. Apidologie 35:91-92.

Prandin, L., N. Dainese, B. Girardi, O. Damolin, R. Piro, and F. Mutinelli. 2001. A scientific note on long-term stability of a homemade oxalic acid water sugar solution for controlling varroosis. Apidologie 32:451-452.

R Development Core Team. 2010. The R Project for Statistical
Computing, R Foundation for Statistical Computing, Vienna, Austria. Available at http://www.R-project.org/ (accessed July 2010).

Rademacher, E., and M. Harz. 2006. Oxalic acid for the control of varroosis in honey bee colonies - a review. Apidologie 37:98-120.

Ramallo, G., S. Díaz-Cetti, M.P. Ojeda, L. Carrasco-Letelier, and Y. Mendoza. 2008. El ácido oxálico como herramienta para el manejo correcto de varroasis. In Jornada de Divulgación: Manejo Sanitario en Apicultura, Colonia. Julio 2008. Serie Actividades de Difusión 539:15-18. INIA La Estanzuela, Colonia, Uruguay.

Suchail, S., D. Guez, and L.P. Belzunces. 2000. Characteristics of imidacloprid toxicity in two Apis mellifera subspecies. Environmental Toxicology and Chemistry 19:1901-1905.

Thompson, H.M., M.A. Brown, R.F. Ball, and M.H. Bew. 2002. First report of Varroa destructor resistance to pyrethroids in the UK. Apidologie 33:357-366.

Tremolada, P., I. Bernardinelli, M. Colombo, M. Spreafico, and M. Vighi. 2004. Coumaphos distribution in the hive ecosystem: Case study for modeling applications. Ecotoxicology 13:589-601.

US EPA. 1996. Honey bee acute contact toxicity test (OPPTS 850 , 3020). Ecological effects test guidelines OPPTS. 850.320/EPA 712-C-96-147. United States Environmental Protection Agency (US EPA), Washington DC, USA.

US EPA. 2006. Trimmed Spearman-Karber method. Statistical analysis for biological methods. United States Environmental Protection Agency (US EPA), Washington DC, USA. Available at $<$ www.epa.gov/nerleerd $>$ (accessed January 2007).

Wallner, K. 1999. Varroacides and their residues in bee products. Apidologie 30:235-248. 